\title{
$\mathrm{A} 6061$ 알루미늄합금 판재의 TIG 용접에서 실험계획법에 의한 최적용접조건의 선정에 관한 연구
}

\author{
정성훈,` · 이도엽* · 김봉율** - 이목영* \\ *포항산업과학연구원 \\ **포항특수용접
}

\section{A Study for TIG Welding Optimization on Bead Shape of A6061 Alloy Sheet using DOE}

\author{
Sunghun Jung*, ${ }^{*}$, Doyup Lee*, Bong Ueoul Kim**, and Mokyoung Lee* \\ *Material Solution Research Group, RIST, Pohang, 37673, Korea \\ **Pohang Special Welding Company, Pohang, 37839, Korea \\ †Corresponding author : choilboy@naver.com \\ (Received October 13, 2017 ; Revised November 21, 2017 ; Accepted March 26, 2018)
}

\begin{abstract}
In this study, aluminum alloy sheets were welded on bead-on-plate using AC type TIG welding machine. Penetration depth and bead width were selected as quality factors of weld bead. Welding conditions were designed with BBD(Box-Benhken Design) method in which the input variables were welding current, arc length and travel speed. TIG welding was done on A6061 alloy sheet for the welding conditions selected by DOE at Ar shielding. The second-order regression equation was obtained using the bead shape measured from TIG welded samples. Verification test was done at the optimum welding condition determined by the surface response diagram derived from the regression equation. The optimum welding condition was welding current $110 \mathrm{~A}$, arc length $1.4 \mathrm{~mm}$ and travel speed $9.6 \mathrm{~mm} / \mathrm{s}$. The penetration depth and the bead width formed at the predicted optimum welding condition were $1.97 \pm 0.010 \mathrm{~mm}$ and $4.65 \pm 0.051 \mathrm{~mm}$. From the result, the regression equation matched with real TIG welding in accuracy $98.5 \%$ and $96.8 \%$ for penetration depth and bead width respectively.
\end{abstract}

Key Words : A6061 sheet, TIG welding, DOE, Bead shape, Regression model

\section{1. 서 론}

대기 중으로 방출되는 이산화탄소는 지구 온난화의 주요 요인으로 인식되는데, 주로 화석연료의 연소과정 에서 배출된다. 수송기기에서 배출가스 저감을 위한 효 과적인 방법중의 하나는 차량의 무게를 감소시키는 것 이다. 미국 에너지성 $(\mathrm{DOE})$ 의 보고에 따르면, 차량의 중량을 $10 \%$ 줄이면 7 8\%의 연비를 증가시켜 이산화 탄소 배출량을 감소시킬 수 있다 ${ }^{1)}$. 차체의 무게를 줄이 기 위하여 고강도강, 알루미늄, 마그네슘, $\mathrm{CFRP}$ 등 무 게 대비 강도가 높은 경량소재의 적용을 증가시키고 있
다. 특히 알루미늄은 규소 다음으로 부존량이 많고, 상 용 금속 중에서는 마그네슘 다음으로 밀도가 낮은 소재 이다. 또한 알루미늄합금은 비교적 역사가 오래되어 다 양한 합금계가 개발되었고, 가공, 용접, 방식 등 부품화를 위한 기술이 개발되었다. 알루미늄합금은 산화성, 열 및 전기전도도가 높기 때문에 종래의 방법으로 용접이 까다 로우나, 용접장비의 발전에 따라 최근에는 무난히 용접이 가능하다. 특히 $\mathrm{TIG}$ 용접은 알루미늄합금의 용접에서 비용이 낮을 뿐만아니라 용접부 성능이 우수하다 ${ }^{2-6)}$.

한편, 복잡한 형상의 부품의 제조에는 아크용접이 일반 적으로 사용되는데, 비철소재 혹은 소규모 생산에는 TIG 용접이 사용된다. $\mathrm{TIG}$ 용접은 필릿, 맞대기, 겹치기 등 
다양한 이음부에 적용이 가능하다. 그러나 입열량이 과 다하면 용접에 따른 열응력이 발생하게 되고, 상당량의 내부응력이 모재 내부에 축적되어 변형에 따른 용접불 량이 발생된다). 알루미늄합금의 TIG 용접부는 빠른 열전달 및 팽창/수축으로 열변형이 많이 발생하지만 관 련 연구는 많이 부족한 실정이다 ${ }^{7)}$.

본 연구에서는 일반적으로 사용되는 고강도 알루미늄 합금인 A6061 소재의 TIG 용접 특성에 대하여 알아 보았다. 용접부 품질인자들은 용입깊이, 비드폭 및 언더 필을 선정하였고, 변수는 용접전류, 이송속도 및 아크길 이를 선정하였다. 적은 실험회수로 다양한 변수들의 영향 을 정밀하고 재현성있게 알아보기 위하여 실험계획법에 따 라 용접을 수행하였다. 또한, 반응표면분석법(Response Surface Methodology)을 적용하여 최적의 비드 형상 을 가지는 용접조건을 선정하였다.

\section{2. 이론적 배경}

TIG 용접에서는 다양한 공정변수들이 용접부 성능에 영향을 미치며, 변수들 사이에 교호작용이 발생하기도 한 다. 다양한 공정변수 및 반응이 존재하는 경우 실험계 획법에 따라 용접조건을 선정하고 실험을 수행하는 것 이 효율적이다. 대표적인 실험계획법은 요인배치법, 반 응표면분석법, 다구찌 실험계획법 등이 있다.

\section{1 반응표면분석법}

반응표면분석법에서 각 인자간의 주 효과와 교호작용 을 확인하기 위해서는 각 효과에 대해 그래프로 나타내 었을 때, 상호 교호작용에 의해 선형이 아닌 비선형으로 나타난다. 따라서 출력변수를 최적화시키기 위한 반응표 면은, 회귀분석(Regression analysis) 방법에 의해 추 정되므로 2 차 회귀모델을 실험계획법의 표에 맞춘 실험 의 결과 값을 통해 구하며, 식(1)과 같이 나타낸당.

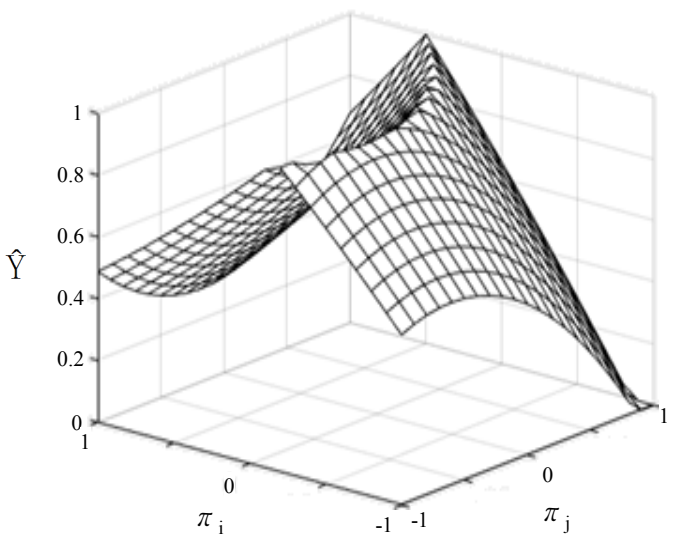

Fig. 1 Plot of response surface methodology

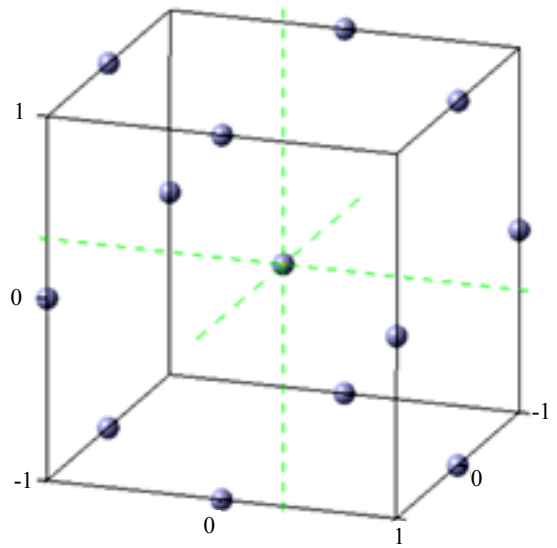

Fig. 2 Box-Behnken design

$$
\hat{\mathrm{y}}=B_{0}+\sum_{i=1}^{k} B_{i} x_{i}+\sum_{i \leq j}^{k} B_{i j} x_{i} x_{j}
$$

여기서 $\hat{\mathrm{y}}$ 는 반응량 $\mathrm{y}$ 의 추정 값이고, $x_{i}, x_{j}$ 는 입력변 수들의 코드변수 값(Coded unit)이며, $B_{0}, B_{i}, B_{i j}$ 는 최소자승법을 적용하여 구한 계수이며 $\mathrm{k}$ 는 요인의 개수 이다. 반응표면분석법은 식 (1) 및 Fig. 2에 나타낸 것과 같이 여러 개의 입력변수 $x_{i}, x_{j}$ 가 복합적인 작용 을 함으로써 어떤 출력변수 $\hat{y}$ 에 영향을 주고 있을 때, 이러한 반응의 변화가 반응표면에 미치는 영향에 대한 통계적인 분석방법인데 ${ }^{9)}$, 직교 블록을 만들기 용이하 고, 2 차 회귀모델을 생성할 수 있으며, 최적의 조건을 찾 을 수 있다. 또한 Fig. 2와 같은 $\mathrm{BBD}(\mathrm{Box}-\mathrm{Benh}-\mathrm{ken}$ Design)방법은 극점의 실험을 제외함으로써 실험 횟수 가 비교적 적어서 반응표면분석에서 많이 사용된다.

\subsection{F-test와 P-value를 통한 회귀모델의 검정 및 호감도 함수}

$\mathrm{BBD}$ 방법에 의해 구해진 회귀식의 유의성에 대한 판 단은 F-test 및 $\mathrm{P}-\mathrm{value}$ 에 의해 결정된다. F-test에 서는, 표본 집단인 $\mathrm{F}_{0}$ 의 값이 모집단인 $\mathrm{F}(\mathrm{a})$ 와 비교하 여 크면 클수록 회귀방정식의 정도가 좋다고 할 수 있 다 ${ }^{10)}$. P-value의 경우, 예측된 통계 값과 다른 결과 값이 나올 확률을 말하는 것으로 $\mathrm{P}-\mathrm{value}$ 의 값이 유의 수준인 0.05 보다 낮을수록 수학적 회귀모델의 정도가 좋다고 판별된다.

호감도 함수는 다중응답에 대한 최적 입력 값을 찾아 주는 방법으로, 회귀모델을 사용하여 각 응답에 대한 호감도 함수의 범위를 $0 \sim 1$ 로 정의했을 때 각 응답에 대한 만족도가 클수록 1 에 근접하고 만족도가 작을수록 0 에 근접한다 ${ }^{11)}$. 


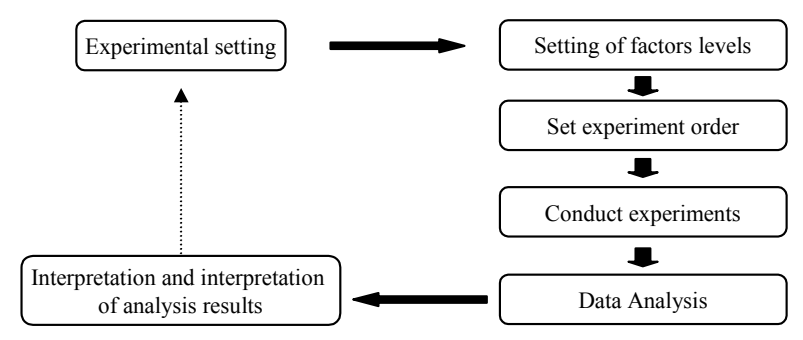

Fig. 3 Typical process of experiment and data analysis

\section{3. 실험방법 및 순서}

용접준비, 조건선정, 용접실험, 데이터분석 및 최적화 는 Fig. 3과 같이 수행하였다. $\mathrm{BBD}$ 방법으로 설계된 조 건으로 용접을 수행하고, 그 실험 결과 값으로부터 수학 적 회귀모델을 도출하고, 회귀모델의 적합도는 ANOVA, F-test, $\mathrm{P}-$ value 및 결정계수 $\left(R^{2}\right)$ 를 사용하여 검정하 였다. 검정 완료 후, 호감도 함수와 반응표면법을 사용 하여 최적화하였으며, 복합 호감도 함수를 사용하여 최 적화 결과 및 회귀모델의 정확도를 검사하였다.

\section{1 용접 조건}

본 실험에 사용된 소재는 용접성과 성형성이 우수하여 널리 사용되는 A6061 합금이었다. Table 1에 A6061 알루미늄 합금의 화학적 성분을 나타내었다. 용접시편은 $160 \mathrm{~mm} \times 75 \mathrm{~mm} \times 2 \mathrm{~mm}$ 로 절단하고, 이면비드 생 성 부근을 에틸알콜로 세적하였다.

알루미늄합금의 TIG 용접에서 비드 형상에 영향을 미치는 인자는 용접전류, 이송속도, 아크 길이, 토치 각 도, 보호가스의 종류와 유량 등이 있다. 예비실험을 통 해 주요 입력변수로 용접전류, 이송속도 및 아크길이를 선정하였다. 토치각도, 전극직경 및 보호가스 등은 고 정변수로 하여 Table 2에 나타내었다. 용접부 품질을 나타내는 출력변수는 용입깊이와 비드폭을 선정하였다.

Table 1 Chemical compositions of A6061 aluminum alloy (wt.\%)

\begin{tabular}{|c|c|c|c|c|c|c|}
\hline $\mathrm{Al}$ & $\mathrm{Cu}$ & $\mathrm{Si}$ & $\mathrm{Mn}$ & $\mathrm{Mg}$ & $\mathrm{Zn}$ & $\mathrm{Fe}$ \\
\hline bal. & $0.15 \sim 0.4$ & $0.4 \sim 0.8$ & 0.15 & $0.8 \sim 1.2$ & 0.25 & 0.7 \\
\hline
\end{tabular}

Table 2 Fixed conditions for TIG welding for A6061 aluminum alloy

\begin{tabular}{|c|c|}
\hline Torch angle $\left(^{\circ}\right)$ & 90 \\
\hline Gas & $\mathrm{Ar}$ \\
\hline Gas flow $(1 / \mathrm{min})$ & 15 \\
\hline Electrodes $(\mathrm{mm})$ & 3 \\
\hline
\end{tabular}

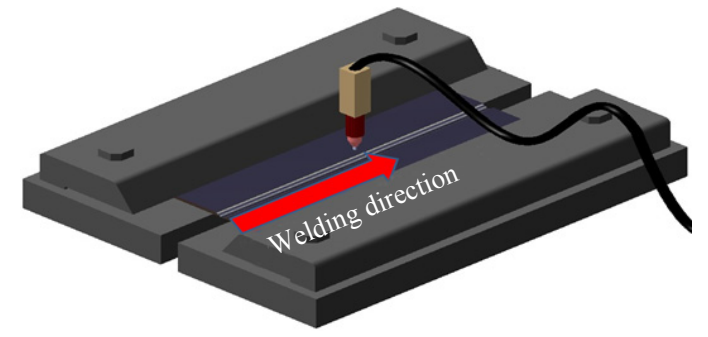

Fig. 4 Setup of welding system

Table 3 Factors and level for experimental design

\begin{tabular}{|c|c|c|c|}
\hline Level & $\begin{array}{c}\mathrm{X}_{1} \\
\text { current (A) }\end{array}$ & $\begin{array}{c}\mathrm{X}_{2} \\
\text { Arc length }(\mathrm{mm})\end{array}$ & $\begin{array}{c}\mathrm{X}_{3} \\
\text { Welding speed }(\mathrm{mm} / \mathrm{s})\end{array}$ \\
\hline 1 & 120 & 3 & 10 \\
\hline 0 & 110 & 2 & 8 \\
\hline-1 & 100 & 1 & 6 \\
\hline
\end{tabular}

용접기는 Fronius사의 Magic Wave 3000 TIG 용접 기이며, $\mathrm{AC}$ 전류로 실시하였다. 용접은 Fig. 4와 같이 아래보기 (1G) 자세로 비드 온 플레이트로 하였으며, 용접길이는 $120 \mathrm{~mm}$ 이었다.

본 연구에서는 목표 형상 치수를 만족하는 용접조건을 찾기 위해, 앞서 설명한 $\mathrm{BBD}$ 방법을 사용하였다. 입력 변수인 용접조건은 전류 $\left(\mathrm{X}_{1}\right)$ 는 $100 \sim 120 \mathrm{~A}$, 아크 길이 $\left(\mathrm{X}_{2}\right)$ 는 $1 \sim 3 \mathrm{~mm}$, 용접속도 $\left(\mathrm{X}_{3}\right)$ 는 $6 \sim 8 \mathrm{~mm} / \mathrm{s}$ 이었으며 Table 3에 나타내었다.

\section{2 용접비드 형상 측정}

용접은 case 당 3회 반복하였으며, 용접 비드의 중간 인 $60 \mathrm{~mm}$ 지점에서 모재를 조직검사용 시편을 채취하 였다. 용접부를 연마 및 부식시켜 광학현미경으로 관찰 하여 상부비드포 $\left(\mathrm{W}_{\mathrm{U}}\right)$, 하부비드폭 $\left(\mathrm{W}_{\mathrm{L}}\right)$, 용입깊이 $(\mathrm{D})$, 언더필 $\left(\mathrm{H}_{U}\right)$, 비드쳐짐 $\left(\mathrm{H}_{S}\right)$ 을 측정하였다.

\section{3 검정 및 용접 품질 평가}

A6061 합금의 TIG 용접부에서 측정한 비드폭과 용 입깊이의 평균값은 통계분석 프로그램인 Minitab 17 을 사용하여 수학적 회귀모델을 도출하였다. 회귀모델 은 유의수준 $5 \%$ 에서 $\mathrm{F}$-test와 P-value로부터 검정하 였다. 용접 비드의 단면형상은 Fig. 5 와 같이 완전용입 과 불완전용입의 두 가지 형상으로 대별되었다. 이면 비드가 생성되지 않은 불완전용접의 경우, 하부비드폭 $\mathrm{W}_{\mathrm{L}}$ 은 유의하지 않았다. 결함의 기준인 $\mathrm{H}_{\mathrm{U}}$ 와 $\mathrm{H}_{\mathrm{S}}$ 역시 불균일하게 나타났다. 본 연구에서 언더필 $\left(\mathrm{H}_{\mathrm{U}}\right)$ 및 비 드쳐짐 $\left(\mathrm{H}_{\mathrm{S}}\right)$ 최대값은 각각 $0.26 \mathrm{~mm}$ 및 $0.38 \mathrm{~mm}$ 인 데, 용접부 형상에 대한 규격(ISO 6520)에서 언더필 


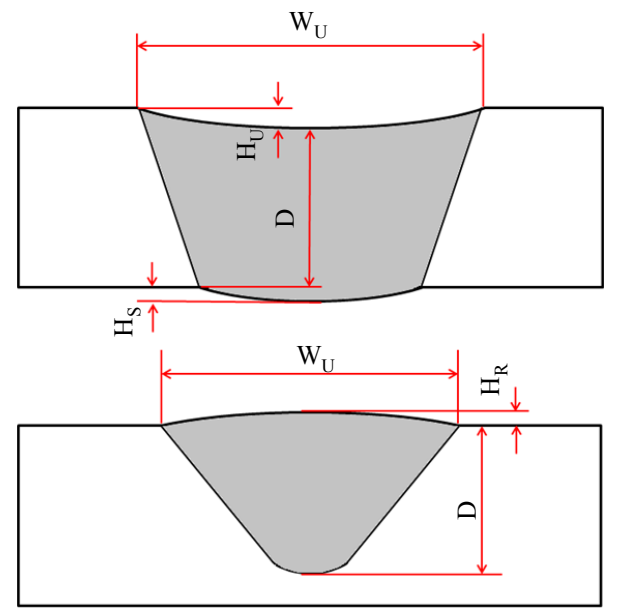

Fig. 5 Nomenclature of the weld bead

$\left(\mathrm{H}_{\mathrm{U}}\right)$ 및 비드쳐짐 $\left(\mathrm{H}_{\mathrm{S}}\right)$ 의 허용한도는 각각 $0.4 \mathrm{~mm}$ 및 $0.5 \mathrm{~mm}$ 이므로, $\mathrm{H}_{\mathrm{U}}$ 와 $\mathrm{H}_{\mathrm{S}}$ 는 품질인자로부터 배제 하여도 무방하다고 판단된다. 용입깊이의 호감도 함수 에서 하한값은 $1.8 \mathrm{~mm}$ (ISO 6520 규격의 중간 단 계), 목표값은 $2 \mathrm{~mm}$ 및 상한 값은 $2.2 \mathrm{~mm}$ 로 설정 하 였다. 비드 폭에 대해서는 특정의 규격이 없기 때문에, 용접부 성능과 변형을 고려하여 적정 비드폭의 범위를 $3.5 \sim 5.5 \mathrm{~mm}$ 로 설정하였다. 용입깊이와 비드폭에 대 한 호감도 함수식을 식(2) 및 (3)에 나타내었다.

(Penetration depth)

$$
\begin{array}{rl}
0 & d<1.8 \\
{\left[\frac{d-1.8}{0.2}\right]} & 1.8 \leq d \leq 2
\end{array}
$$$$
D F 1=\left[\frac{d-2.2}{-0.2}\right] \quad 2.0 \leq d \leq 2.2
$$

$$
0 \quad d>2.2
$$

(Bead width)

$$
0 \quad d<3.5
$$

$$
\begin{array}{rr}
D F 2= & 3.5 \leq d \leq 4.5 \\
{\left[\frac{d-3.5}{1.0}\right]} & 4.5 \leq d \leq 5.5 \\
0 & d>5.5 \\
D=\frac{\left(w_{1} \times D F_{1}\right)+\left(w_{2} \times D F_{2}\right)}{2} &
\end{array}
$$

비드 폭과 용입 깊이의 두 가지 용접 품질을 평가할 각 호감도 함수를 식 (4)와 같이 복합 호감도 함수로 바꾸어 주었다. 여기서 $w_{1}$ 및 $w_{2}$ 는 각각 비드 폭 및 용입 깊이의 중요도인데, $1: 1$ 의 비율로 설정하였다. 검 증된 회귀모델과 호감도 함수식을 사용하여, 만족도가
가장 높은 비드 형상으로 최적화하였다 ${ }^{12)}$.

\section{4. 결과 및 고찰}

\section{1 용접 비드 측정}

$\mathrm{BBD}$ 방법으로 설계된 조건으로 용접한 용접비드의 측정결과를 Table 4 및 Fig. 6에 나타내었다. 조건 1, $3,6,7,8$ 및 12 의 용접부는 불완전용입이었으며, 11 및 13 은 언더필이 형성되지 않았다. 상기의 조건에서는 반응과 입력변수의 상관성이 없을 뿐만아니라 외관상으 로 쉽게 판별이 가능하기 때문에 정밀하고 강건한 회귀 식을 도출하기 위하여 회귀모델에 포함시키지 않았다.

\subsection{ANOVA 결과}

$\mathrm{BBD}$ 방법으로 설계한 총 15 cases의 실험계획표 (Table 4)에서 용접한 용접비드의 형상을 측정한 값으 로 수학적 회귀모델을 생성하였다. 관심영역에서 입력 변수인 용접전류 $\left(\mathrm{X}_{1}\right)$, 아크길이 $\left(\mathrm{X}_{2}\right)$ 및 용접 속도 $\left(\mathrm{X}_{3}\right)$ 에 대한 출력변수인 비드폭과 용입 깊이에 관한 회귀식 은 식 (5) 및 (6)에 나타내었다.

$$
\begin{aligned}
\text { Bead Width } & =5.310+0.7175 \chi_{1}-0.0263 \chi_{2} \\
& -1.1812 \chi_{3}+0.084 \chi_{1}^{2}+0.056 \chi_{2}^{2} \\
& -0.019 \chi_{3}^{2}-0.160 \chi_{1} \chi_{2}+0.030 \chi_{1} \chi_{3} \\
& -0.222 \chi_{2} \chi_{3}
\end{aligned}
$$

Table 4 Box-Behnken design and the test results

\begin{tabular}{|c|c|c|c|c|c|c|c|c|}
\hline \multirow{2}{*}{ No. } & \multicolumn{3}{|c|}{ Coded variables } & \multicolumn{5}{|c|}{ Response $(\mathrm{mm})$} \\
\cline { 2 - 9 } & $\mathrm{X}_{1}$ & $\mathrm{X}_{2}$ & $\mathrm{X}_{3}$ & $\mathrm{~W}_{\mathrm{U}}$ & $\mathrm{W}_{\mathrm{L}}$ & $\mathrm{D}$ & $\mathrm{H}_{\mathrm{U}}$ & $\mathrm{H}_{\mathrm{S}}$ \\
\hline 1 & -1 & -1 & 0 & 4.54 & - & 2.09 & 0 & - \\
\hline 2 & 1 & -1 & 0 & 6.79 & 5.19 & 1.99 & 0.13 & 0.23 \\
\hline 3 & -1 & 1 & 0 & 3.97 & - & 0.95 & 0 & - \\
\hline 4 & 1 & 1 & 0 & 5.91 & 5.32 & 1.82 & 0.26 & 0.38 \\
\hline 5 & -1 & 0 & -1 & 5.86 & 3.28 & 2.02 & 0.08 & 0.18 \\
\hline 6 & 1 & 0 & -1 & 6.99 & - & 1.81 & 0 & - \\
\hline 7 & -1 & 0 & 1 & 3.70 & - & 1.43 & 0 & - \\
\hline 8 & 1 & 0 & 1 & 4.84 & - & 2.03 & 0 & 0.15 \\
\hline 9 & 0 & -1 & -1 & 6.31 & 5.25 & 1.87 & 0.15 & 0.31 \\
\hline 10 & 0 & 1 & -1 & 7.03 & 5.80 & 1.67 & 0.23 & 0.18 \\
\hline 11 & 0 & -1 & 1 & 4.12 & 0.73 & 2.01 & 0 & 0.18 \\
\hline 12 & 0 & 1 & 1 & 3.85 & - & 0.84 & 0 & - \\
\hline 13 & 0 & 0 & 0 & 5.34 & 3.01 & 2.03 & 0 & 0.08 \\
\hline 14 & 0 & 0 & 0 & 5.26 & 2.68 & 1.93 & 0.10 & 0.18 \\
\hline 15 & 0 & 0 & 0 & 5.48 & 2.82 & 1.87 & 0.13 & 0.10 \\
\hline
\end{tabular}




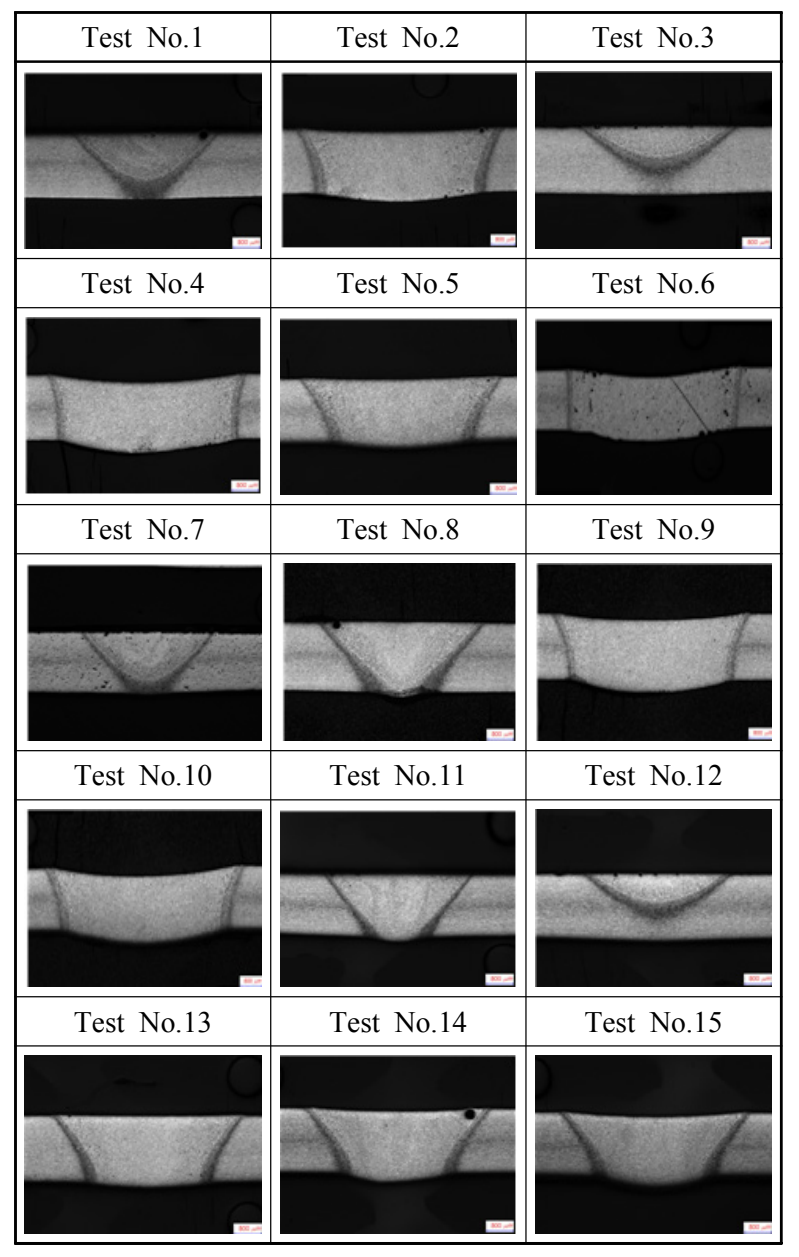

Fig. 6 Shape of the weld bead tested according to BBD

$$
\begin{aligned}
\text { Penetration } & =1.9433+0.1450 \chi_{1}-0.3350 \chi_{2} \\
& -0.1325 \chi_{3}-0.0029 \chi_{1}^{2}-0.2279 \chi_{2}^{2} \\
& -0.1179 \chi_{3}^{2}+0.2425 \chi_{1} \chi_{2}+0.2025 \chi_{1} \chi_{3} \\
& -0.2425 \chi_{2} \chi_{3}
\end{aligned}
$$

용접 비드 형성에 미치는 각 인자들의 주효과와 교호 작용을 Fig. 7에 도시하였다. 본 실험조건 범위에서 용 입깊이는 용접전류의 변화에 비례하였다. 아크길이와 이송속도의 변화에는 반비례하였는데, 아크길이 변화에 상대적으로 크게 영향을 받았다. 변수간의 상호작용을 의미하는 교호작용은 전류, 아크길이 및 이송속도의 3 가지 변수에 대해 존재하였다. 즉, 고전류-짧은 아크길 이, 고전류-이송속도, 짧은 아크길이-이송속도에서 교 호작용이 예상되었다. 비드폭은 용접전류의 변화에 비 례하였고 이송속도의 변화에는 반비례하였다. 아크길이 의 변화에는 미소하게 반비례하였다. 비드폭에서 용접 전류-이송속도, 아크길이-이송속도의 교호작용은 없었 으며, 용접전류-아크길이 사이에서 아크길이 변화의 효 과가 미소하여 교호작용은 유의한 것으로 보기 어렵다.

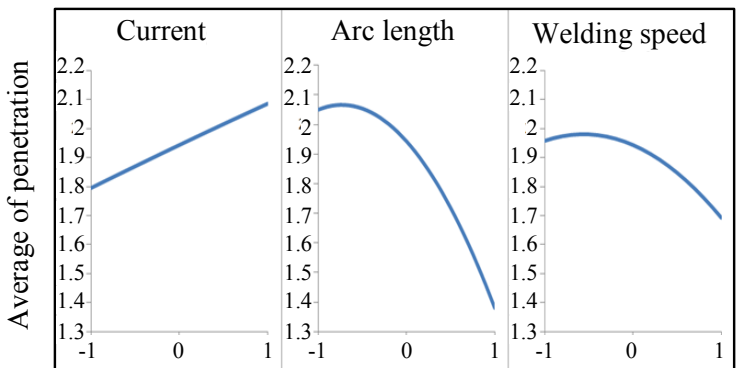

(a) Main effect of input variables on penetration depth

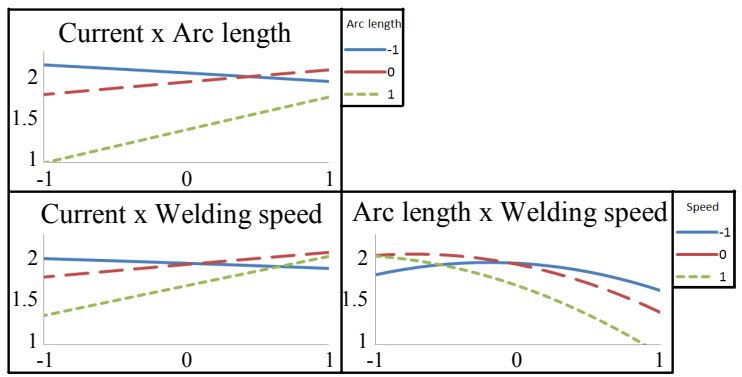

(b) Interaction effect between input variables on penetration depth

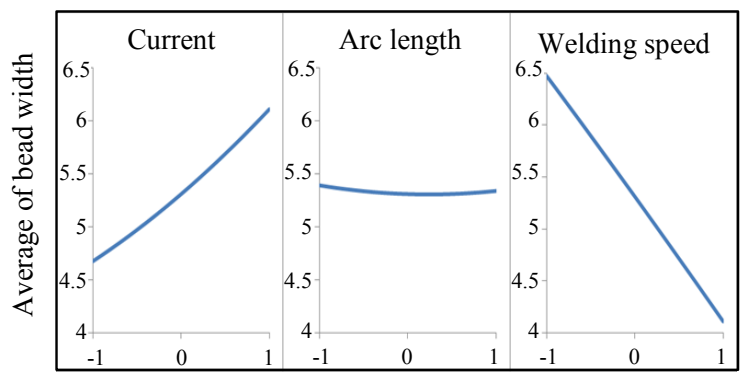

(c) Main effect of input variables on bead width

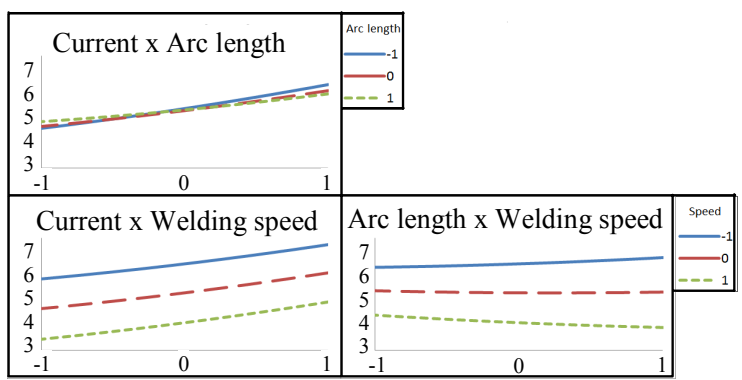

(d) Interaction effect between input variables on bead width

Fig. 7 Main and interaction effects of each factors on the bead shape

\section{3 검 정}

ANOVA 해석으로 얻은 회귀모델인 식 (5)과 식 (6) 을 F-test와 P-value를 통해 검증하고자 한다. Table 5 에 본 연구에서의 ANOVA 분석표를 기재하였다. Ftest에서 회귀모델을 평가할 $\mathrm{F}_{0}$ 값은 $\mathrm{F}(\mathrm{a})$ 보다 약 5 배 이상 크며, P-value는 0.001로 유의수준인 0.05보 다 작은 것을 알 수 있다. 따라서 용입 깊이와 비드 폭의 회귀모델을 $\mathrm{F}$-test 및 $\mathrm{P}-\mathrm{value}$ 로 검정을 실시한 결과, 
Table 5 Regression analysis results of weld bead width and penetration depth

\begin{tabular}{|c|c|c|c|c|}
\hline & P-value & $R^{2}$ & $F_{0}$ & $F(\alpha)$ \\
\hline Penetration depth & 0.001 & $97.90 \%$ & 25.94 & \multirow{2}{*}{4.77} \\
\hline Bead width & 0.001 & $97.65 \%$ & 23.06 & \\
\hline
\end{tabular}

본 회귀모델은 유의하다고 할 수 있다 ${ }^{13)}$.

\section{4 최적조건 도출 및 검증실험}

$\mathrm{A} 6061$ 합금에 대해 $\mathrm{BBD}$ 방법으로 설계한 조건으로 $\mathrm{TIG}$ 용접하여 도출된 회귀식(식 5 및 6) 및 호감도 함수(식 2 4)에서 구한 반응표면도를 Fig. 8에 나타 내었다. 반응표면도로부터 도출한 최적의 용접비드형상 은 용입깊이 $2.0 \mathrm{~mm}$ 및 상부비드폭 $4.5 \mathrm{~mm}$ 이며, 그에 상응하는 용접조건은 용접전류 0 , 아크길이 -0.6 및 이 송속도 0.8 이었으며, 직교좌표계로 찾아낸 실제 값을 Table 6에 나타내었다.

본 회귀식 및 반응표면도로부터 예측된 최적의 용접조 건(Table 6)에서 아크길이 및 이송속도는 각각 $1.4 \mathrm{~mm}$

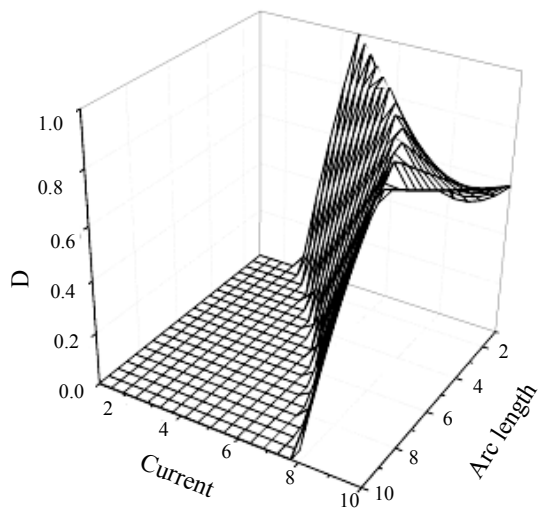

(a) Desirability response of current and arc length on penetration depth

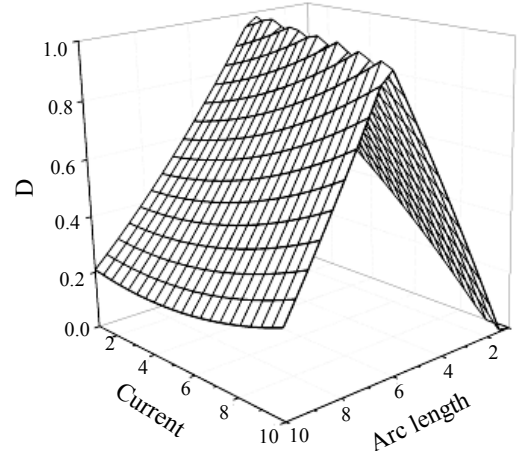

(b) Desirability response of current and arc length on bead width

Fig. 8 Desirability response for penetration depth and bead width at welding speed $=0.799$ )
Table 6 Optimum welding conditions derived from the regression equations

\begin{tabular}{|c|c|c|c|c|c|}
\hline \multicolumn{3}{|c|}{ Coded variables } & \multicolumn{3}{c|}{ Natural variables } \\
\hline $\mathrm{X} 1$ & $\mathrm{X} 2$ & $\mathrm{X} 3$ & $\begin{array}{c}\text { Welding } \\
\text { current (A) }\end{array}$ & $\begin{array}{c}\text { Arc } \\
\text { length } \\
(\mathrm{mm})\end{array}$ & $\begin{array}{c}\text { Travel } \\
\text { speed } \\
(\mathrm{mm} / \mathrm{s})\end{array}$ \\
\hline 0 & -0.610 & 0.799 & 110 & 1.39 & 9.597 \\
\hline
\end{tabular}
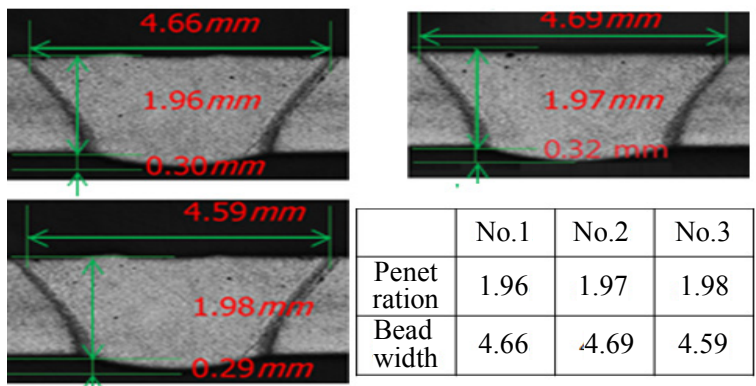

\begin{tabular}{|c|c|c|c|}
\hline & No.1 & No.2 & No.3 \\
\hline $\begin{array}{l}\text { Penet } \\
\text { ration }\end{array}$ & 1.96 & 1.97 & 1.98 \\
\hline $\begin{array}{l}\text { Bead } \\
\text { width }\end{array}$ & 4.66 & 4.69 & 4.59 \\
\hline
\end{tabular}

Fig. 9 Weld bead shapes after verification test

및 $9.6 \mathrm{~mm} / \mathrm{s}$ 로 실험적으로 유의한 조건으로 일반화하 여 3회 검증실험을 진행하였다. 검증 용접실험의 비드형 상 및 측정값을 Fig. 9에 나타내었다. 회귀식으로 예측한 최적용접조건의 용접비드는 용입깊이 $1.97 \pm 0.010 \mathrm{~mm}$ 및 비드폭 $4.65 \pm 0.051 \mathrm{~mm}$ 이었다. 언더필은 형성되지 않 았으며 비드쳐짐은 $0.3 \mathrm{~mm}$ 로 ISO 규격의 허용 범위이 내의 우수한 비드를 형성 하였다. A6061 합금의 TIG 용접에서 용입깊이 및 비드폭에 대한 본 회귀식의 예측 정확도는 각각 $98.5 \%$ 및 $96.8 \%$ 이었다.

\section{5. 결 론}

두께 $2.0 \mathrm{~mm}$ 의 A6061 합금의 TIG 용접에서 용접비 드 형상에 대한 수학적 회귀모델에 관한 연구결과는 다 음과 같다.

1) 기초실험을 통해 비드 형상에 영향을 미치는 주요 인자로서 용접전류, 아크길이 및 이송속도를 각각 100 $120 \mathrm{~A}, 1 \sim 3 \mathrm{~mm}, 6 \sim 8 \mathrm{~mm} / \mathrm{sec}$ 으로 선정하였다.

2) $\mathrm{BBD}(\mathrm{Box}-\mathrm{Behnken}$ Design)방법으로 설계한 조건으로 용접을 수행하고, 용입 깊이와 비드 폭에 대 한 2차 회귀식(식 5 및 6)을 도출하였다.

3) 수학적 회귀모델을 통해 A6061 합금의 TIG용접 에서 용입깊이와 비드폭에서 각각의 입력변수에 대한 주효과 및 교호작용을 확인하였다. 용입깊이에는 아크길 이 및 비드폭에는 이송속도가 크게 영향을 미쳤다. 비 드폭에서는 교호작용이 뚜렷하지 않았다.

4) 반응표면도로부터 최적의 용접비드를 형성하는 조건 을 선정하였는데, 용접전류 $110 \mathrm{~A}$, 아크길이 $1.4 \mathrm{~mm}$ 및 
이송속도 $9.6 \mathrm{~mm} / \mathrm{s}$ 이었다.

5) 본 연구에서 도출한 회귀식에 대한 검증 결과, 용 입깊이 $1.97 \pm 0.010 \mathrm{~mm}$ 및 비드폭 $4.65 \pm 0.051 \mathrm{~mm}$ 이었다. 비드폭 및 용입깊이에 대한 회귀 모델의 정확 도는 각각 $98.5 \%$ 및 $96.8 \%$ 이었다.

\section{후기}

본 논문은 2017년도 정부(산업통상자원부)의 재원으 로 산업기술혁신사업 $(\mathrm{N} 0001850)$ 의 지원을 받아 수행 되었습니다.

ORCID: Sunghun Jung: https://orcid.org/0000-0002-3307-6437

ORCID: Doyup Lee: http://orcid.org/0000-0002-3330-4866

ORCID: MokyoungLee: http://orcid.org/0000-0001-7227-5415

\section{References}

1. Mokyoung Lee, Sung-Hun Jung, Trends of Advanced Multi-Material Technology for Light Materials based on Aluminum, Journal of Welding and Joining, 34(5) (2016), 19-26 https://doi.org/10.5781/JWJ.2016.34.5.19

2. Chang-Yong Lee, Seon-Kyu Kim, Properties of 7075 aluminium alloy by friction stir welding, The Korean Welding \& Joining Society, (2004), 159-161

3. Kearns, W. H., Welding Handbook, American Welding Society, 1984, 276-311

4. Sang-pil Kim and Tae-min Hong, A study on the resistance spot welding of Aluminum-Alloy( I ), The Korean Welding \& Joining Society, (1994), 93-97

5. Byung Young Moon, Ki Yeol Lee, Kyu Sun Kim, The Effect of Welding Conditions on Tensile Characteristics and Thermal Stress of Al 5083 Alloy Applied to Co-en vironmental Leisure Ships, Journal of the Society of Naval Architects of Korea, 40(6) (2014), 548-555

https://doi.org/10.3744/SNAK.2014.51.6.548

6. Tae-Jin Kim, Improvement of Welding Performance of MIG Arc Welding using Superposition Ac Pulse, Journal of the Korean Institute of Illuminating and Electrical Installation Engineers, 22(10) (2008), 141-149

7. Okada, Furukawa-Sky Review, 4(2008), 18-26

8. T. Kim, H. Park, S. Rhee, Y.K. Oh, Optimization of Resistance Spot Welding Process for TRIP Sheets using Response Surface Methodology, The Korean Society of Mechanical Engineers, (2002), 1131-1136

9. Jin Soo Jung, Hee Keun Lee, Young Whan Park, Prediction of Tensile Strength for Plasma-MIG Hybrid Welding Using Statistical Regression Model and Neural Network Algorithm, Journal of Welding and Joining, 34(2) (2016), 67-72

https://doi.org/10.5781/JWJ.2016.34.2.67

10. Seok-chul Yun, Jae-Woong Kim, Selection of Optimal Welding Condition in Root-pass Welding of V-groove Butt Joint, Journal of KWJS, 27(1), (2009), 95-101

11. Y. S. Tarng and W. H. Yang, Optimisation of the weld Bead Geometry in Gas Tungsten Arc Welding by the Taguchi Method, The International Journal of Advanced Manufacturing Technology, 14 (1998), 549-554

12. Hyoung-Jin Park, Seungho Ahn, Munjin Kang, Sehun Rhee, A Study on the Optimization for a V-groove GMA Welding Process Using a Dual Response Method, Journal of KWJS, 26(2) (2008), 85-91

13. Young-kil Yun, Jae-Woong Kim, Seok-chul Yun, Selection of an Optimal Welding Condition for Back Bead Formation in GMA Root Pass Welding, Journal of KWJS, 28(5) (2010) 86-92 